\title{
Cytomegalovirus infection in Guillain-Barré syndrome: a retrospective study in Brazil
}

\author{
Infecção por citomegalovirus na Síndrome de Guillain-Barré: um estudo retrospectivo \\ no Brasil
}

\author{
Mario Emilio Teixeira DOURADO JUNIOR ${ }^{1,2}$, Bruno Fernandes de SOUSA 1 , Nathaly M. Coelho da COSTA \\ Selma Maria Bezerra JERONIMO 2,3,4
}

\begin{abstract}
Background: Guillain-Barré syndrome (GBS) is currently the most common cause of acute flaccid paralysis worldwide. Risk factors for GBS include previous viral or bacterial infections or vaccination. Recently, an outbreak of Zika virus led to an outbreak of GBS in Latin America, mostly in Brazil, concomitant to continuous circulation of dengue virus serotypes. However, there is no study about cytomegalovirus (CMV) infection as a risk for GBS in Brazil. Objectives: In this study, we report a series of cases of GBS with the aim of determining the prevalence of CMV and the characteristics associated with the infection. Methods: A cohort of 111 GBS cases diagnosed between 2011 and 2017 in Natal, northeastern Brazil, was studied. Presence of CMV IgM antibodies was determined by means of electrochemiluminescence. The analysis was performed considering CMV infection status and the clinical outcome. Results: We found seroprevalence of $15.3 \%(n=17)$ for CMV. CMV patients were younger (26 vs. 40; $p=0.016$ ), with no apparent gastrointestinal ( $p=0.762$ ) or upper respiratory infections ( $p$ $=0.779$ ) or sensory loss $(p=0.03)$. They presented more often with a classic GBS sensorimotor variant $(p=0.02)$ and with a demyelinating pattern in electrophysiological studies $(p<0.001)$. Conclusion: In Brazil, the clinical-epidemiological profile of GBS associated with CMV infection is similar to that described in other countries. Better understanding of the relationship between infectious processes and GBS is a key component of the research agenda and assistance strategy for global health initiatives relating to peripheral neuropathic conditions.
\end{abstract}

Keywords: Cytomegalovirus infections; Guillain-Barré syndrome; epidemiology; Brazil.

\section{RESUMO}

Introdução: Aproximadamente 2/3 dos pacientes com a Síndrome de Guillain-Barré (SGB) apresentam alguma doença infecciosa precedente. Recentemente, uma epidemia de infecção por o vírus Zika resultou em surto de SGB na América Latina, principalmente no Brasil, concomitante à circulação contínua de sorotipos do vírus da Dengue. No entanto, não há estudo sobre a infecção por citomegalovírus (CMV) como fator de risco para SGB no Brasil. Objetivos: Neste estudo, relatamos uma série de casos de SGB com o intuito de determinar a prevalência de CMV e as características associadas à infecção. Métodos: Foi estudada uma coorte de 111 casos de SGB diagnosticados entre 2011 e 2017 na cidade de Natal, capital do estudo do Rio Grande do Norte, nordeste do Brasil. A presença de anticorpos IgM CMV foi determinada por eletroquimiluminescência. A análise foi realizada considerando o status de infecção por CMV e os achados clínicos. Resultados: Foi observada uma soroprevalência de 15,3\% ( $n=17)$ para o CMV. Os casos de CMV eram mais jovens (26 vs. 40, $p=0,016)$, sem história de infecção gastrointestinal $(p=0,762)$ ou respiratória superior $(0,779)$ ou perda sensorial $(p=0,03)$. Apresentaram-se mais frequentemente como uma variante sensitiva-motora clássica da SGB ( $p=0,02)$ e subtipo desmielinizante nos estudos eletrofisiológicos ( $p$ <0,001). Conclusão: No Brasil, o perfil clínico-epidemiológico do SGB associado à infecção por CMV é semelhante ao descrito em outros países. O melhor entendimento das relações entre processos infecciosos e SGB é um componente-chave de uma agenda de pesquisa e estratégia de assistência para iniciativas globais de saúde em neuropatia periférica.

Palavras-chave: infecção por citomegalovírus; síndrome de Guillain Barré; epidemiologia; Brasil.

\footnotetext{
1 Universidade Federal do Rio Grande do Norte, Centro de Ciências da Saúde, Departamento de Medicina Integral, Natal RN, Brazil.

¿Universidade Federal do Rio Grande do Norte, Instituto de Medicina Tropical do Rio Grande do Norte, Natal RN, Brazil.

${ }^{3}$ Universidade Federal do Rio Grande do Norte, Centro de Biociências, Departamento de Bioquímica, Natal RN, Brazil.

4 Intituto Nacional de Ciências e Tecnologia de Doenças Tropicais, Natal RN, Brazil.

Mario Emilio Teixeira Dourado (1D https://orcid.org/0000-0002-9462-2294; Bruno Fernandes de Sousa (D) https://orcid.org/0000-0002-6186-5193; Nathaly M. Coelho da Costa (D) https://orcid.org/0000-0003-2909-2386; Selma Maria Bezerra Jeronimo (D) https://orcid.org/0000-0002-4784-9904 Correspondence: Mario Emilio Teixeira Dourado Junior; Email:medourado@ufrnet.br.

Conflict of interest: There is no conflict of interest to declare.

Support: This work was supported by CAPES (grant number 440893/2016-0) and CNPq (grant number 88881.130729/2016-01).

Authors' contributions: METD and SMBJ were involved in the study concept and design and in acquisition of data; BFS, NMCC, METD and SMBJ analyzed and interpreted the data; METD wrote the first draft of the manuscript; BFS and METD performed the statistical analysis; All authors read and approved the manuscript.

Received on April 02, 2020; Received in its final form on September 16, 2020; Accepted on September 28, 2020.
} 


\section{INTRODUCTION}

Guillain-Barré syndrome (GBS) is the most common cause of acute flaccid paralysis worldwide. Demyelinating and axonal subtypes of the syndrome are distinguished by their histological and electrophysiological features and occur in varying proportions across different geographical regions of the world. Clinical variants such as classic sensorimotor and Miller-Fisher syndrome, and others, have been well characterized $^{1,2}$. GBS is commonly triggered after infections, among which Campylobacter jejuni enteritis and primary cytomegalovirus (CMV) infections are the most frequent ${ }^{1}$. We previously reported that about $32 \%$ of GBS cases in Natal, Brazil, were due to $C$. jejuni infection ${ }^{3}$. Interest in other causes triggering GBS has increased consequent to outbreaks associated with arboviral infections ${ }^{1}$. However, there is no study about the frequency of CMV infection as a triggering cause of GBS in Brazil. In this study, we report on a series of GBS cases that were positive for IgM antibodies against CMV, which were diagnosed from 2011 to 2017 in a reference center in northeastern Brazil. We report on their clinical outcomes and discuss the association of CMV infection and GBS.

\section{METHODS}

\section{Background information}

Data collected retrospectively from a cohort of 111 patients with GBS in the state of Rio Grande do Norte (RN), Brazil, between January 2011 and December 2017, were assessed and analyzed. This cohort was established from GBS cases hospitalized in public and private hospitals in the city of Natal, capital of the state of Rio Grande do Norte. Part of this cohort has been described previously ${ }^{4}$.

GBS was defined using the Asbury and Cornblath criteria ${ }^{5}$. The diagnoses of acute inflammatory demyelinating polyradiculoneuropathy (AIDP) and acute motor axonal neuropathy (AMAN) subtypes were made based on the existing electrophysiological criteria for motor nerve-conduction study results ${ }^{6,7}$. Acute axonal sensory and motor neuropathy (AMSAN) was defined as absence of demyelinating features, as in Ho's criteria ${ }^{6}$, with a reduction in sensory nerve action potential amplitude $>50 \%$ of the lower limit of normal in at least two nerves. For instance, the electrophysiological pattern of GBS-subtype acute nodo-paranodopathies, which is part of the spectrum of the axonal subtype, was defined using serial recordings, as follows: (1) conduction block or reduced distal compound muscle action potential (CMAP) amplitude, which promptly resolved without development of excessive temporal dispersion, as observed in the cohort; (2) conduction block followed by low-amplitude CMAP from all nerve stimulation sites without persistent features of demyelination; and (3) low-amplitude CMAP on early recordings, which did not improve during follow-up ${ }^{8}$. All cases were examined by the same neurologist (M.E. Dourado), who also performed nerve-conduction studies.

The degree of severity was assessed at the peak of illness. The GBS Disability Scale grading system (Hughes scale), of 0-6 was used (state 0, normal; state 1, minimal signs and symptoms, able to run; state 2 , able to walk without assistance; state 3 , able to walk $10 \mathrm{~m}$ with aid; state 4, confined to bed or chairbound; state 5 , needs ventilatory support; state 6 , deceased) ${ }^{9}$. Cases were classified as severe (Hughes grade of 4 or more) or mild (Hughes grade of 3 or less). The outcome measurements for this study were the Hughes grade at 6 months and the number of days to recover the ability to walk (days to walking). A poor outcome was defined as a Hughes grade of 3 or more at 6 months, which corresponded to the inability to walk $5 \mathrm{~m}$ independently.

Blood samples collected prior to use of immunoglobulin were obtained at hospital admission and were assayed for the presence of CMV-specific IgM antibodies by means of electrochemiluminescence (Elecsys CMV, Cobas, Roche Diagnosis $\mathrm{GmbH}$ ) and for the presence of GM1 antibodies using ELISA, as described in a previous study3.

\section{Statistical analysis}

The characteristics of patient subgroups were compared using the chi-square and Fisher's exact tests, Student's t test, and the Mann-Whitney U test.

\section{Ethical considerations}

The protocol for this study was reviewed and approved by the Ethics Review Board of the Federal University of Rio Grande do Norte (Universidade Federal do Rio Grande do Norte), under the numbers CEP-UFRN 046/03 and CEPUFRN 198/09.

\section{RESULTS}

\section{General features of the Guillain-Barré subjects}

Our GBS case series consisted of 50 females and 61 males, with a mean age of 36 years (range from 1 to 87). Among the 111 subjects, one died after the diagnosis. CMV-specific IgM antibodies were found in 17 of the 111 patients (15.3\%).

\section{Characteristics of the CMV/GBS patients}

The analysis was performed considering the results from the CMV serological studies, with subjects grouped as either CMV+/GBS (CMV-positive) or CMV-/GBS (CMV-negative). The $\mathrm{CMV}+/ \mathrm{GBS}$ subjects were significantly younger than the CMV-/GBS subjects (mean age 26 vs. 40; $p=0.016$ ), but there was no sex difference between the two groups ( $p=$ 0.290). There was no difference between the groups' preceding events (diarrhea or influenza-like illness). 
Regarding clinical examination, sensory loss occurred more frequently in the CMV+/GBS patients ( $82.3 \%$ vs. $53 \% ; p=$ 0.03). Although facial palsy was more common in the $\mathrm{CMV}+$ / GBS patients (70\% of CMV+/GBS vs. $47.8 \%$ of CMV-/GBS), this difference was not significant $(p=0.114)$. All the subjects, except three cases, underwent at least one electrodiagnostic study, and 52 underwent more than one. The CMV+/GBS patients also more often presented a classic sensorimotor clinical variant of GBS $(p=0.02)$ and electrophysiological subtypes of AIDP $(p<0.01)$, and they had longer hospitalization (mean 31 days vs. 20 days; $p=0.038$ ). However, they did not differ significantly from the CMV-/GBS group with regard to mechanical ventilation (MV) requirement, Hughes score, days on MV, nadir or days to recover walking. A summary of the major findings is provided in Table 1 . All the subjects were immunocompetent, with no history of immunodeficiency or use of immunosuppressant therapy.

Only one (5.8\%) of the CMV+/GBS patients had an axonal subtype (AMAN). Acute motor and sensory axonal neuropathy and acute nodo-paranodopathy subtypes were identified

Table 1. Clinical characteristics of the Guillain-Barré patients, according to previous infection.

\begin{tabular}{|c|c|c|c|c|}
\hline Variable & Total $(n=111)$ & $\mathrm{CMV}+/ \mathrm{GBS}(\mathrm{n}=17)$ & CMV-/GBS $(n=94)$ & $p$-value \\
\hline Age, years $($ mean $\pm S D) *$ & $36 \pm 21$ & $25 \pm 17$ & $38 \pm 21$ & 0.016 \\
\hline Gender (female:male) & $50: 61$ & $10: 7$ & $40: 54$ & 0.290 \\
\hline \multicolumn{5}{|l|}{ Preceding events } \\
\hline Diarrhea, n (\%) & $28(25.2 \%)$ & $5(29.4 \%)$ & $23(24.4 \%)$ & 0.762 \\
\hline Influenza-like symptoms, n (\%) & $35(31.5 \%)$ & $6(35.3 \%)$ & $29(30.8 \%)$ & 0.779 \\
\hline \multicolumn{5}{|l|}{ Clinical data } \\
\hline Sensory loss* & $64(57.6 \%)$ & $14(82.3 \%)$ & $50(53.0 \%)$ & 0.030 \\
\hline Facial palsy & $57(51.3 \%)$ & $12(70.0 \%)$ & $45(47.8 \%)$ & 0.114 \\
\hline Bulbar dysfunction & $10(9.0 \%)$ & $3(17.0 \%)$ & $7(7.0 \%)$ & 0.180 \\
\hline Ataxia & $26(23.4 \%)$ & $3(17.0 \%)$ & $23(24.4 \%)$ & 0.757 \\
\hline $\mathrm{MV}$ requirement & $21(18.9 \%)$ & $4(23.5 \%)$ & $17(18.8 \%)$ & 0.736 \\
\hline Hughes score & & & & 0.098 \\
\hline 0 & 0 & 0 & 0 & \\
\hline 1 & 0 & 0 & 0 & \\
\hline 2 & $2(1.8 \%)$ & $1(5.9 \%)$ & $1(1.1 \%)$ & \\
\hline 3 & $30(28.0 \%)$ & $1(5.8 \%)$ & $29(32.2 \%)$ & \\
\hline 4 & $52(48.6 \%)$ & $10(58.8 \%)$ & $42(46.6 \%)$ & \\
\hline 5 & $23(21.5 \%)$ & $5(29.4 \%)$ & $18(20.0 \%)$ & \\
\hline Classification Mild & & & & 0.184 \\
\hline \multirow[t]{2}{*}{ Severe } & $32(29.6 \%)$ & $2(11.7 \%)$ & $30(32.9 \%)$ & \\
\hline & $75(69.4 \%)$ & $15(88.2 \%)$ & $60(65.9 \%)$ & \\
\hline \multicolumn{5}{|l|}{ Variants of GBS } \\
\hline Classic sensorimotor* & 60 & 14 & 46 & $p=0.02$ \\
\hline Pure motor & 23 & 1 & 22 & $p=0.188$ \\
\hline Paraparetic & 3 & 0 & 3 & $p=0.238$ \\
\hline Bilateral facial palsy with paresthesia & 3 & 0 & 3 & $p=0.238$ \\
\hline Pure sensory & 6 & 2 & 4 & $p=0.211$ \\
\hline Miller-Fisher syndrome & 15 & 0 & 15 & $p=0.66$ \\
\hline Bickerstaff brainstem encephalitis & 1 & 0 & 1 & $p=0.538$ \\
\hline \multicolumn{5}{|l|}{ Electrophysiological GBS subtype } \\
\hline Demyelinating* & 61 & 15 & 46 & $p<0.01$ \\
\hline Axonal & 27 & 1 & 26 & $p=0.06$ \\
\hline Equivocal & 20 & 1 & 19 & \\
\hline Unrealized & 3 & 0 & 3 & \\
\hline
\end{tabular}


Table 1. Cont.

\begin{tabular}{|c|c|c|c|c|}
\hline Variable & Total $(n=111)$ & $\mathrm{CMV}+/ \mathrm{GBS}(\mathrm{n}=17)$ & CMV-/GBS $(n=94)$ & $p$-value \\
\hline \multicolumn{5}{|l|}{ Clinical evolution and prognosis } \\
\hline MV, days (mean) & $22(4-60)$ & $17(15-60)$ & $18(4-45)$ & 0.308 \\
\hline Nadir (mean) & $7(1-24)$ & $7(2-14)$ & $7(1-24)$ & 0.398 \\
\hline Hospital, days (mean)* & $22(3-75)$ & $31(5-65)$ & $20(3-75)$ & 0.038 \\
\hline Days to walking (mean) & $36(3-546)$ & $37(4-100)$ & $36(3-546)$ & 0.949 \\
\hline Antiganglioside antibodies $(n=75)$ & $(n=11)$ & $(n=64)$ & & \\
\hline GM1 IgG & $14(18.63 \%)$ & 01 & $14(21.8 \%)$ & $P=0.0854$ \\
\hline
\end{tabular}

CMV: Cytomegalovirus; GBS: Guillain-Barré syndrome; MV: Mechanical ventilation.

only in CMV-/GBS patients. All patients with Miller-Fisher syndrome had no or only slight peripheral sensory electrophysiological abnormalities (equivocal subtype).

Presence of anti-GM1 IgG antibodies was found in 75 GBS subjects: $11 \mathrm{CMV}+/ \mathrm{GBS}$ and $64 \mathrm{CMV}-/$ GBS. Fourteen of the CMV-/GBS (21.8\%) presented anti-GM1 antibodies, and these patients all presented the axonal subtypes. None of the CMV+/GBS patients were positive for anti-GM1 IgG antibodies.

\section{DISCUSSION}

The aim of this study was to investigate the prevalence of CMV infection among GBS cases diagnosed in Rio Grande do Norte and to determine whether there was any association with clinical and electrophysiological characteristics. To best of our knowledge, no data on the relationship between CMV and GBS in Brazil had previously been published.

CMV infection is reported to be the second most common infection that precedes GBS, after $C$. jejuni $i^{1}$. The association between CMV and GBS was first reported in $1967^{10}$ and was then validated by other case series and case control studies. In those studies, on European and North American case series, the frequency of CMV infection with GBS ranged from $8 \%$ to $15 \%^{11-16}$. Most of those patients had had a preceding febrile illness, usually one affecting the upper respiratory tract, but most CMV infections were subclinical. Those studies established that the patients with CMV+/GBS had a clinical pattern that differed from that of patients with other infections. They were significantly younger, initially had a severe course, as indicated by high frequency of respiratory insufficiency, and often developed cranial nerve involvement and severe sensory loss ${ }^{12,13,15,16}$.

In our case series, out of the 111 subjects, $15.3 \%$ showed evidence of recent infection with CMV, as determined by the presence of IgM. In the state of Rio Grande do Norte, to our knowledge, there was only one previous study that assessed the frequency of anti-CMV IgM antibodies, which was conducted in a population of kidney donors and recipients. That study showed frequencies of anti-CMV IgM antibodies of $1 \%$ and $2.4 \%$, respectively, for these two groups ${ }^{17}$.

Although that study was small, it seems that GBS subjects more frequently present recent CMV infection. Our $\mathrm{CMV}+$ / GBS patients were more likely to be young, to develop sensory defects and to present a classic sensorimotor clinical variant. Among these $\mathrm{CMV}+$ /GBS patients, $88.2 \%$ were classified as initially having a severe course (Hughes grade of 4 or more), but the long-term sequelae were milder, with a mean time to recovery of walking of 37 days. A pattern of acute demyelinating neuropathy pattern was the most frequent electrophysiological subtype in our cohort with $\mathrm{CMV}+$ /GBS, which was similar to findings in previous reports ${ }^{12,13,15,16}$. Only one CMV+/GBS patient had AMAN, and none had acute nodoparanodopathies or acute motor and sensory axonal neuropathy subtypes.

Only the patients with the axonal subtype who were CMV-negative were positive for anti-GM1. Therefore, we did not identify any correlation between CMV+/GBS and antiGM1. However, it has now been established that the epitopes of the axonal subtype are gangliosides GM1 and GDla, which are expressed on the motor axolemma, while the target molecules in AIDP remain unknown ${ }^{18}$. In previous studies, we found that patients with GBS and anti-GM1 antibodies presented more distal muscle weakness, fewer sensory deficits, more axonal degeneration and more C. jejuni infection ${ }^{3}$. Anti-GM2 antibodies, which were not tested in our study, are expressed in GBS following infection with CMV ${ }^{19}$. In Japanese subjects, anti-Moesin antibodies were frequently found in patients with CMV-related AIDP. This protein is expressed in the Schwann cell processes at the nodes of Ranvier and is crucial for myelination. Moesin is a possible immunological target molecule of pathogenic autoantibodies in patients with CMV-related AIDP ${ }^{20}$. Further studies are needed to investigate whether antibodies are induced by CMV infections and whether they are involved in the pathogenesis of CMVrelated GBS.

In our study, the prevalence of specific IgM antibodies was $15.3 \%$, which was consistent with previous reports. We could not determine whether the CMV infection was primary or reactivation, because it was difficult to distinguish them 
based only on an IgM assay. One possible mitigating strategy would be to assess the IgG avidity, as performed in some studies $^{16}$. Thus, the lack of other tests was an important limitation of our study, as was the absence of control subjects. However, to the best of our knowledge, this is the first study with the aim of identifying CMV seroprevalence and associated factors in the setting of GBS, in a Brazilian state.

In conclusion, CMV infection is an important infection preceding the onset of GBS in Rio Grande do Norte, Brazil, with a distinct clinical and electrophysiological profile, similar to reports from other countries. Better understanding of the relationship between infectious processes and GBS is a key component of a research agenda and assistance strategy for global health.

\section{ACKNOWLEDGEMENT}

We would like to thank Kaline Lucena Fonseca, MD, of the Clinical Pathology Center, for her help in making the diagnosis of CMV.

\section{REFERENCES}

1. Willison $\mathrm{HJ}$, Jacobs BC, van Doorn PA. Guillain-Barré syndrome. Lancet. 2016 Aug 13;388(10045):717-27. https://doi.org/10.1016/ s0140-6736(16)00339-1

2. Leonhard SE, Mandarakas MR, Gondim FAA, Bateman K, Ferreira MLB, Cornblath DRet al. Diagnosis and management of GuillainBarré syndrome in ten steps. Nat Rev Neurol. 2019 Nov;15(11):67183. https://doi.org/10.1038/s41582-019-0250-9

3. Dourado ME, Duarte RC, Ferreira, LC, Queiroz JW, Illa I, Perez-Perez G, Guerrant RL, Jeronimo SM. Anti-ganglioside antibodies and clinical outcome of patients with Guillain-Barre syndrome in northeast Brazil. Acta Neurol Scand. 2003 Aug;108(2):102-8. https://doi. org/10.1034/j.1600-0404.2003.00103.x

4. Dourado Júnior MET, Fernandes UT, Ramos ES, Vital ALF, Urbano JCC, Queiroz JW, Jeronimo SMB. Egos has reduced capacity to predicts GBS prognosis in Northeast Brazil. Acta Neurol Scand. 2018 Nov;138(5):459-62. https://doi.org/10.1111/ane.12995

5. Asbury AK, Cornblath DR. Assessment of current diagnostic criteria for Guillain-Barre syndrome. Ann Neurol. 1990;27(Suppl):S21-4. https://doi.org/10.1002/ana.410270707

6. Ho TW, Mishu B, Li CY, Gao CY, Cornblath DR, Griffin JW, et al. GuillainBarré syndrome in northern China. Relationship to Campylobacter jejuni infection and anti- glycolipid antibodies. Brain. 1995;118:597605. https://doi.org/10.1093/brain/118.3.597

7. Hadden RD, Cornblath DR, Hughes RA, ZielasekJ, Hartung HP, Toyka KV, et al. Electrophysiological classification of Guillain-Barré syndrome: clinical associations and outcome. Ann Neurol. 1998 Nov;44(5):780-8. https://doi.org/10.1002/ana.410440512

8. Uncini A, Susuki K, Yuki N. Nodo-paranodopathy: beyond the demyelinating and axonal classification in anti-ganglioside antibodymediated neuropathies. Clin Neurophysiol. 2013 Oct;124(10):192834. https://doi.org/10.1016/j.clinph.2013.03.025

9. Hughes RA, Newsom-Davis JM, Perkin GD, Pierce JM. Controlled trial prednisolone in acute polyneuropathy. Lancet. 1978 Oct 7;2(8093):750-3. https://doi.org/10.1016/s0140-6736(78)92644-2

10. Klemola E, Weckman N, Haltia K. The Guillain-Barre' syndrome associated with acquired cytomegalovirus infection. Acta Med Scand. 1967 May;181(5):603-7. https://doi.org/10.1111/j.0954-6820.1967. tb07283.x
11. Dowling PC, Cook SD. Role of infection in Guillain-Barre syndrome: laboratory confirmation of herpesviruses in 41 cases. Ann Neurol. 1981;9(Suppl):44-55. https://doi.org/10.1002/ana.410090709

12. Winer JB, Hughes RAC, Anderson MJ, Jones DM, Kangro H, Watkins RFP. A prospective study of acute idiopathic neuropathy. II. Antecedent events.J Neurol Neurosurg Psychiatry. 1988 May; 51(5):613-8. https://doi.org/10.1136/jnnp.51.5.613

13. Jacobs BC, Rothbarth PH, van der Meché FG, Herbrink P, Schmitz $\mathrm{PI}$, de Klerk MA, et al. The spectrum of antecedent infections in Guillain-Barré syndrome: a case-control study. Neurology. 1998 Oct;51(4):1110-5. https://doi.org/10.1212/wnl.51.4.1110

14. Yuki N. Infectious origins of, and molecular mimicry in, GuillainBarré and Fisher syndromes. Lancet Infect Dis. 2001 Aug;1(1):29-37. https://doi.org/10.1016/s1473-3099(01)00019-6

15. Visser LH, van der Meche FGA, Meulstee J, Rothbarth P, Jacobs BC, Schmitz PIM, et al. Cytomegalovirus infection and Guillain-Barre syndrome: the clinical, electrophysiologic and prognostic features. Neurology. 1996 Sept;47(3):668-73. https://doi.org/10.1212/ $w n l .47 .3 .668$

16. Orlikowski D, Porcher R, Sivadon-Tardy V, Quincampoix JC, Raphaël $J C$, Durand MC, et al. Guillain-Barre' syndrome following primary cytomegalovirus infection: a prospective cohort-study. CID 2011. Clin Infect Dis. 2011 Apr;52(7):837-44. https://doi.org/10.1093/cid/cir074

17. Joventino KMS. Monitoramento da infecção por citomegalovírus em pacientes submetidos a transplante renal [Mestrado]. [Natal (RN)]: Universidade Federal do Rio Grande do Norte, Centro de Biociência; 2017.62p.

18. Yuki N, Kuwabara S. Axonal Guillain-Barré syndrome: carbohydrate mimicry and pathophysiology. J Peripher Nerv Syst. 2007 Dec;12(4):238-49. https://doi.org/10.1111/j.1529-8027.2007.00153.x

19. Jacobs BC, van Doorn PA, Groeneveld JH, Tio-Gillen AP, van der Meche FG. Cytomegalovirus infections and anti-GM2 antibodies in GuillainBarre syndrome. J Neurol Neurosurg Psychiatry. 1997 Jun;62(6):6413. https://doi.org/10.1136/jnnp.62.6.641

20. Sawai S, Satoh M, Mori M, Misawa S, Sogawa K, Kazami T, et al. Moesin is a possible target molecule for cytomegalovirus-related Guillain-Barré syndrome. Neurology. 2014 Jul 8;83(2):113-7. https:// doi.org/10.1212/wnl.0000000000000566 